\title{
The Benefit of State Audit and Significance to Enhancing the Validity of Vietnamese State Budget Accounting
}

\author{
Pham Quang Huy \\ University of Economics Ho Chi Minh City, Vietnam
}

\begin{abstract}
For achievement of common goals, state accounting is used and applied by the government for adjusting the activities of public organizations that are in compliance with the social-economic policies in the country. Indeed, public sector has been playing a pivotal role in supporting the government's aspirations in the development in any countries. To conduct these responsibilities, public entities have to provide valuable financial information for making the decisions. These figures will be extracted from accounting documents and reports, because accounting is a financial resources measurement of any firms. As a result, public sector accounting, also known as budget accounting, is an important tool for reflecting the governmental transactions to general statements. However, there are some limitations or errors in the public sector accounting reports. Therefore, state audit is established for checking, monitoring, and inspecting figures made from pubic accounting. Moreover, from the past to the present, very little research has been conducted to define the usefulness of public auditing to general accounting. With causes necessary for examining economic activities of any organizations, the main purpose of this paper is to identify the theory of state budget accounting, the activities, characteristics, and tasks of state audit for improving the value of accounting data in the Vietnamese public sector. This article has given five points of view as well as five solutions for enhancing the state audit.
\end{abstract}

Keywords: accounting, auditing, public sector accounting, state audit, state budget accounting

\section{Introduction}

Together with the operations of private companies, a number of public sector entities are also working with numerous activities. Organizations of all fields and sizes need to implement a streamlined accounting system in order to accurately record and report the transactions. Accounting, also known as accountancy, is considered as a company's tool for reflection and measurement of financial resources and account information. This information is posted in various financial accounts and disclosed to decision-makers and other parties in a specific format. Most people say that the matters which occurred in public sector entities are different from the events happened in companies. Therefore, the firms need figures as effective as making decisions about public sector accounting. In many countries, the state accounting regime has some differences in recording, summarizing, preparing reports, etc.. Due to many different purposes, the corruptions or embarrassments in governmental budget have been made. As a result, the state audit has formed in order to control and inspect the state figures and to clearly make transparency reports for whole nations (Palmer, 2008).

Pham Quang Huy, lecturer, Public Sector Accounting Division, School of Accounting, University of Economics Ho Chi Minh City. Email: pquanghuy@ueh.edu.vn. 
In fact, there are a lot of researches in public sector accounting, such as accrual matters, cash basis accounting matters, the development of international public sector accounting standards in countries, financial management in public sector, etc.. However, in the world, from the past to the present, very little research has been conducted to examine the benefits of government auditing with public sector knowledge. With the above reasons, the content of this paper will focus on five sections as follows: (1) introduction; (2) literature review and research method about the public sector accounting and state auditing; (3) legal status, tasks, types, contents, and audit process of Vietnamese state audit; (4) solutions for developing the value of state audit in Vietnam and other countries; and (5) conclusions.

\section{Literature Review and Research Method}

\section{Literature Review}

There is no doubt that governmental finance is a foundation and an important part of state accounting (Le, 2009). State finance always represents the public interest of any country and has a close relationship with the interests of businesses, organizations, families, individuals, and foreign countries as well. All subjects in the society have the obligation to contribute the cash extracted from part of their income to the state. Taxation is the main source of state finance and this is the revenue that has compulsory items required by law. In addition, state also has some revenues as follows: revenues from the sale or lease of state assets; voluntary contributions of the people; and aid and debt targets under state agreement. The state expenditure consists of regular expenditure, expenditure for development and investment, and other expenses (Ramadhan, 2009).

The structure of expenditures will depend on the task of state and the ability of the economy in each period. As a mechanism for creating the fund, state finance can be divided into parts such as the state budget, state financial funds outside the state. Moreover, Colquhoun (2011) revealed that as assigned in accordance with the system of government, the state finance has been included: governmental state finance and local level (province, district, and commune). The concept of state finance is broader than the concept of state budget. Hence, the decentralization of management state finance does not coincide completely with the decentralization of management government budget, and the decentralization of management budget is the core of decentralized finance. For managing the state finance, the government must use its management tools as the environment and transmission of the impact of management entity (the state) to the managed object. The tools for controlling state finance can be cited as follows: law, estimation, and accounting. Among three factors, state accounting is supposed as an instrument for reflecting the picture of state finance. It is said that state audit has also been considered as an essential field for most areas in the society (Hoang, 2008).

The purposes of state accounting are to record, process, and provide information about the entire situation and the movement of financial resources (in the form of taxes, debt, regular expenditures, development and investment spending, paying debt, etc.). The governmental accounting helps to manage the state property, conducts the official inspection, and makes economic decisions for measuring the effectiveness of using state financial assets (Radcliffe, 2012). State accounting is part of the general accounting in the national economy. Therefore, it must comply with the generally accepted accounting principles and methods (Amran \& Devi, 2008). However, state accounting has a certain independent position in the general accounting system, associated with the financial-economic cycle through the state budget and state finance besides the state budget funds. Although there are some controversies, it can be believed that state audit is an office which is significant to monitor the use and reception of budget of any departments in any countries (Mai, 2013). 


\section{Research Method}

This paper adopts the content analysis approach. By using the quality researching method, through the analysis of the current situation in Vietnam, this paper will provide the limitations in operations and processes of auditing. In addition, the author has also reviewed the legal documents from the past to the present and discovers some unsuitable clauses and gives some ideas for reform.

\section{General Framework of Vietnamese State Audit}

\section{Definition}

According to Thinh (2010) and Hoang (2009), audit activities of the state audit are considered as: the examination, evaluation, and verification of the accuracy and truthfulness of financial statements; compliance with law; economic nature, efficiency, and effectiveness in the management; and the use of state budget, money, and property. Principles for audit activities of the state audit are independence, compliance with law only, honesty, and objectivity (Chan, 2009).

\section{Legal Status, Functions, Tasks, Powers, and Organization of State Audit}

The state audit is a government body which has a power function in a country as follows:

(1) Legal status: The state audit is a professional agency specialized in state financial examination, set up by the National Assembly, operates independently, and complies with the law only;

(2) Functions: The state audit has the function of conducting financial audit, compliance audit, or operational audit with respect to agencies and organizations managing and/or using state budget, money, and property;

(3) Tasks: These are some main duties that audit has to perform, such as:

(a) To decide and organize the implementation of annual audit plans and report them to the National Assembly and the government before implementation;

(b) To submit the state audit's opinions to the National Assembly for considering and deciding on the state budget estimates, deciding on the allocation of central budget and the national important projects and works, and approving the final settlements of the state budget;

(c) To join the National Assembly's Economic and Budget Committee and other National Assembly agencies as well as the government in considering and verifying reports on state budget estimates, schemes on allocation of the central budget, adjustment of state budget estimates, or on arrangement of budget for important national projects and works, which have been decided by the National Assembly, and the final settlements of the state budget;

(d) To report annual audit results and results of the implementation of audit proposals to the National Assembly; send audit reports to the Nationality Council and the National Assembly's committees, the state president, the government, and the prime minister; and supply audit results to the Finance Ministry, the people's councils of localities where audits are conducted, and other agencies;

(e) To publicize audit reports and transfer dossiers to investigation agencies and other state agencies competent to examine and handle cases, which show signs of law violations by organizations or individuals and are detected through audit activities;

(f) To manage audit dossiers and keep secret accounting documents and figures as well as information on operations of audited entities; 
(4) Powers: These are some main rights that audit got, such as:

(a) To request audited entities and relevant organizations and individuals to supply full, accurate, and timely information and documents in service of audit;

(b) To request audited entities to act in response to the state audit's conclusions and proposals on their violations in financial statements and violations; and propose measures to redress shortcomings in operations of entities which it has detected and proposed;

(c) To propose competent state agencies to handle violations of law committed by organizations or individuals, which have already been clarified through audit activities;

(d) To request competent agencies to handle, according to law, organizations and individuals that obstruct its audit activities or supply untruthful information and documents to it and state auditors;

(e) To entrust or hire audit enterprises to audit agencies or organizations managing and/or using the state budget, money, and property; and take responsibility for the accuracy of audit data, documents, and conclusions provided by audit enterprises;

(f) To propose the National Assembly, the National Assembly Standing Committee, the government, the prime minister, and other state agencies to amend and/or supplement mechanisms, laws, and policies appropriately.

\section{Types and Contents of Audit}

Types of audit include financial audit, compliance audit, and operational audit (Tyer \& Willand, 1997). Three types of audit are described in Figure 1. The State Auditor General shall decide on the type of audit for each audit.

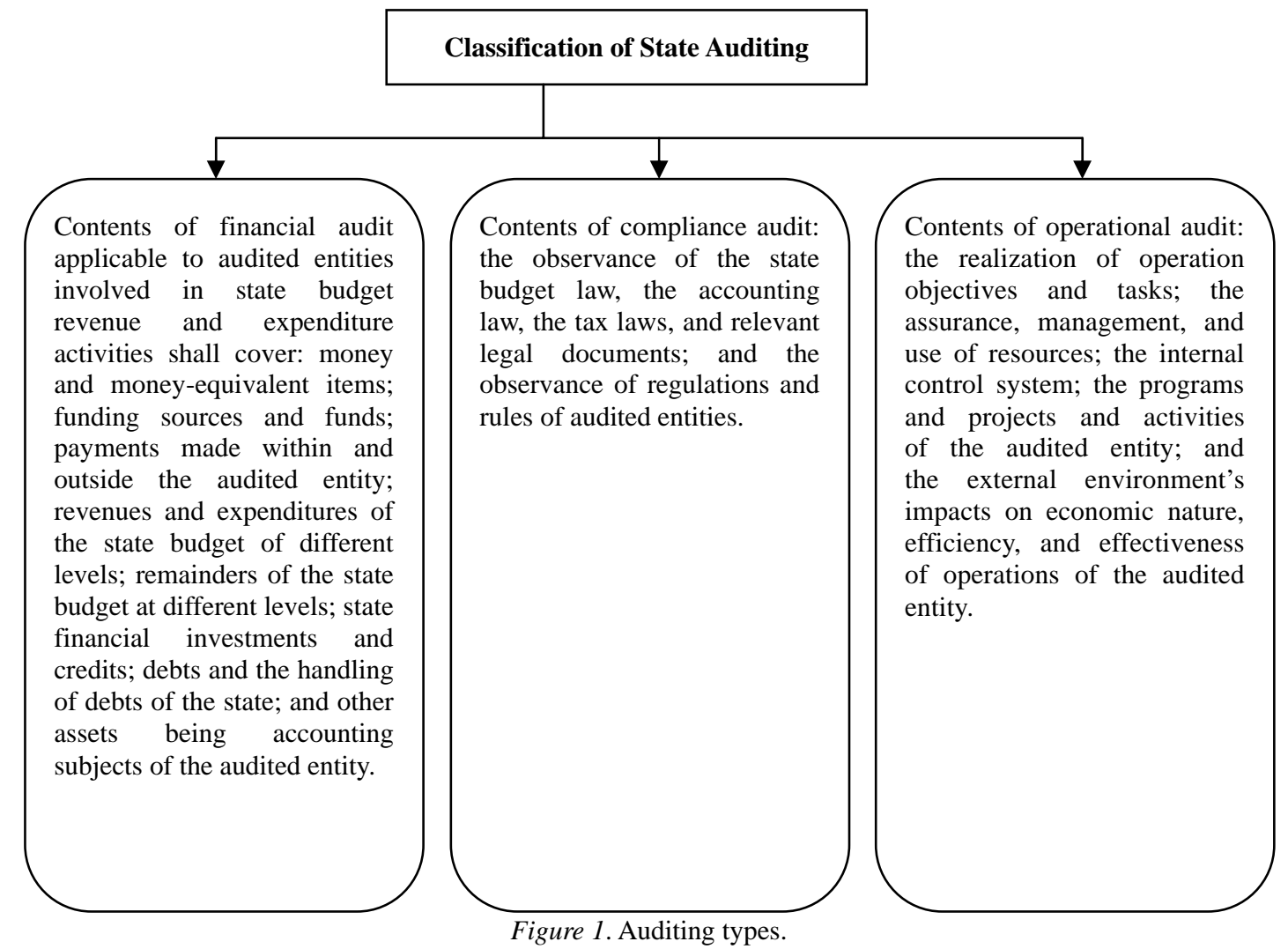




\section{State Auditing Processes}

Steps of the audit process are:

(1) Preparing audit: surveying, gathering, and evaluating information on the internal control system, financial situation, and other information related to the audited entity. After that, an audit plan should be elaborated;

(2) Auditing: By applying audit professional and operational approaches to gather and evaluate audit evidence and conduct examination, comparison, and verification, an audit delegation must conduct the audit at the defined audited entity and comply with the audit objectives, contents, scope, venue, and duration as stated in the audit decision of the State Auditor General;

(3) Making and sending the audit report: Upon the end of an auditing year and an audit, the state audit shall make an audit report, clearly stating its evaluations, verifications, conclusions, and proposals on audited contents;

(4) Inspecting the implementation of audit conclusions and proposals: Auditors must elaborate plans and organize the inspection of audited entities in the complete and timely implementation of its conclusions and proposals regarding the latter's violations in financial statements and violations of law; the application of measures to redress shortcomings in their operations and results thereof, according to conclusions and proposals of the state audit.

\section{Results and Solutions for Enhancing the Value of State Audit}

\section{Viewpoints on Development of the State Audit}

The strategy, for development of the state audit for a long-term purpose, must demonstrate the following viewpoints:

(1) This body should be transferred to a main and efficient tool of the state in examining and controlling the management and use of the state budget, money, and assets and of the National Assembly at all levels in supervising and deciding on important national and local issues;

(2) It should be expanded in line with the government's points of view, guidelines, and policies and in accordance with the state's legal system, and the independence of activities should make sure that audit can carry out all its functions and tasks, better adapting to all requirements of the management of the state budget, money, and assets in the process of renewal;

(3) It should grow in line with the objectives of administrative reform in general and public finance reform in particular, and its suitable scope should be determined in each period to meet the requirements of assigned tasks. The state audit should be built into a professional and modern agency with a reasonably developed quantity and improving quality and a neat apparatus that operates efficiently and effectively. Modern information technologies (IT) should be extensively utilized to audit management and operations (Lienert, Rab, Nguyen, Vu, Mahajan, Shetty, Kwakwa, \& Van Der Linde, 2014);

(4) The state must adopt policies to prioritize necessary resources for the organizational structure and state audit's operation, investment in the development of IT system in the sector, and support for training the sector's personnel to cope with international integration requirements;

(5) It should also be operated to the needs of international economic integration and in accordance with international principles and practices and Vietnam's practical conditions. 


\section{Solutions for the Development of the State Audit}

The major contents of the solution for development of the state audit consist of five matters as follows:

(1) Creation of complete and comprehensive legal grounds for the organization and operation of the state audit: studying and proposing the addition, at an appropriate time, to the Vietnamese constitution of some articles or clauses; and revising laws and relevant legal documents on the state audit in order to ensure the consistency and uniformity of provisions of the legal system on the organization and operation of the state audit;

(2) About the development of the organizational apparatus system of the audit office: to further develop and improve the organizational apparatus system of the state audit after the current model of centralized and unified management, consisting of advisory unit specialized state audit offices at the central level, regional state audit offices, and non-business units; and to strive to basically complete the organizational structure and build its organizational apparatus with a complete structure and sufficient personnel for proper operation;

(3) The development of human resources: developing the contingent of cadres, civil servants, and public employees which is sufficient in quantity and rational in professional and rank structure. Furthermore, building a contingent of state audit cadres, civil servants, and public employees who have a firm political stance, good professional ethics, sound professional skills, and professionalism commensurate with requirements of the audit profession and the international integration;

(4) The strategy for raising audit quality: comprehensively raising audit quality in the three aspects of capability, effectiveness, and efficiency;

(5) The strategy for development of physical foundations, public information and propaganda, and scientific and IT development: formulating priority policy to vigorously mobilize resources for building special physical foundations for the entire system of the state audit; and intensifying and diversifying forms of intensive and extensive public information and propaganda about the law on audit organization and operation as well as audit practices through formulation of specific plans combined with inspection and assessment of their implementation.

\section{Conclusion}

In the stage of development and management of the economy by the current trend of integration, especially when Vietnam joined the World Trade Organization, the development of Vietnamese state audit is very significant and strategic for the next long-term periods for the following reasons: (1) the position, role, and importance of state audit in general and economic management and management of public assets in particular; (2) the practice in Vietnam's socio-economic status and the inevitable requirements of state audit in the trend of integration management; (3) international economic integration; and (4) the current limitations of the Vietnamese state budget accounting. For the first three reasons, they have been mentioned many times in previous research papers. Here, this paper would like to refer to the fourth reason, which is the current limitation of the state accounting and auditing in Vietnam. Despite the fact that state fields have been growing for a long time in Vietnam, they still have some limitations because of the quantity and quality of official accountants, such as poor management skills, lack of economic understanding, inadequate academic information. So, the first important step is to build a new audit approach. This should be introduced to all staffs of organizations so that the auditing work will have been done independently and completely. 
With the efforts of the government, there have been a lot of solutions for improving the quality of state audit. Hence, in recent years, the operations of the state audit have achieved important results which are greater than previous years, contributing to the reform of the financial system and the national budget, building up the nation's financial transparency and efficiency, recovering the state budget revenues that may not be obtained due to mistakes and errors in the process of budget and financial management, and contributing to anti-corruption, thrift practice, and waste combat. Vietnam needs to orient to make a better environment of state audit. State audit is one of the factors that contribute to ensuring and maintaining the economy and the efficiency of economic activities. Through its activities, the state audit indicates the use of state funds in each sector, each field, each enterprise, and the factors that hinder the effectiveness of activities in the economy. On the other hand, the state audit also provides an important basis of reliable data to make distributions, to operate a state budget effectively, consistent with the practical situation of each sector and industry areas, and to eliminate unreasonable expenses that cause losses to the budget. Over all the values and benefits, state audit has to be a tool for financial examination of the state for giving the right and authority to the nation's citizens for checking or controlling the budget. Certified comments by the state audit are to ensure the reliability of budget financial information and the general economic groups in particular.

\section{References}

Amran, A., \& Devi, S. S. (2008). The impact of government and foreign affiliate influence on corporate social reporting: The case of Malaysia. Managerial Auditing Journal, 23(4), 386-404.

Chan, J. L. (1996). Budget accounting in China: Continuity and change. Research in Governmental and Nonprofit Accounting, 9 , 147-174.

Colquhoun, P. (2011). The production of legitimacy in New Zealand local government auditing. Working Paper No. 86.

Hoang, H. (2008). Discuss the situation and solution: Improve the quality of the state budget. Auditing Review, 2(2), 6-8.

Hoang, V. C. (2009). Solutions to prevent, detect negative process, participate in the audit of the state audit. Auditing Review, 4(3), 5-9.

Le, H. Q. (2009). Discuss solutions to improve the quality and speed up audit of the state audit. Accounting and Auditing Review, 1(2), 10-14.

Lienert, I., Rab, H., Nguyen, M. V., Vu, Q. H., Mahajan, S., Shetty, S., Kwakwa, V., \& Van Der Linde, G. (2014). Revising Vietnam's state budget law (2002): Proposals drawing on international experience (English). Retrieved from http://documents.worldbank.org/curated/en/2014/04/20334144/revising-vietnams-state-budget-law-2002-proposals-drawing-i nternational-experience

Mai, T. H. M. (2013). State auditing with the investment in public sector: Case of Vietnam. Journal of Modern Accounting and Auditing, 9(10), 1334-1341.

Palmer, L. A. (2008). Considering bias in government audit reports: Factors that influence the judgments of internal government auditors. International Journal of Business Communication, 45(3), 265-285.

Radcliffe, V. S. (2012). The election of auditors in government: A study of politics and the professional. Accounting and the Public Interest, 12(1), 38-61.

Ramadhan, S. (2009). Budgetary accounting and reporting practices in Bahraini governmental units: An empirical study. International Business Review, 18(2), 168-183.

Thinh, V. V. (2010). Some issues related with development the state audit in Vietnam. Auditing Review, 4(1), 12-16.

Tyer, C., \& Willand, J. (1997). Public budgeting in America: A twentieth century retrospective. Journal of Public Budgeting, Accounting, and Financial Management, 9(2), 189-219. 